\title{
GATA2 Gene
}

National Cancer Institute

\section{Source}

National Cancer Institute. GATA2 Gene. NCI Thesaurus. Code C97552.

This gene is involved in both DNA binding and transcriptional regulation. 